\title{
Co-transplantation of umbilical cord mesenchymal stem cells and peripheral blood stem cells in children and adolescents with refractory severe aplastic anemia
}

\author{
fangfang Yuan ${ }^{1}$, MingYue Zhao ${ }^{1}$, Nan $\mathrm{Ma}^{2}$, Shanggang Zong ${ }^{3}$, Gangping $\mathrm{Li}^{1}$, Yuewen Fu${ }^{1}$, \\ and Li Wang ${ }^{3}$ \\ ${ }^{1}$ Affiliated Tumor Hospital of Zhengzhou University \\ ${ }^{2}$ Henan Academy of Medical Sciences \\ ${ }^{3}$ Henan Academy of Medical Sciences
}

November 18, 2021

\begin{abstract}
Objectives: The purpose of our study was to analyze the co-transplantation efficacy of umbilical cord mesenchymal stem cells (UC-MSCs) and peripheral blood stem cells (PBSCs), which is considered as a novel approach for refractory severe aplastic anemia (RSAA) in children and adolescents. Methods: Thirty-two children and adolescents with RSAA were retrospectively reviewed. According to the source of PBSCs, all patients were divided into two groups (matched sibling donor group and matched unrelated donor group). Engraftment, graft-versus-host disease (GVHD) and overall survival (OS) were analyzed. Results: No adverse events related to UC-MSCs infusion occurred in all patients. The median time for neutrophil engraftment was $13\left(10^{\sim} 23\right)$ days and $15\left(11^{\sim} 28\right)$ days for platelet. Grade I II acute GVHD and moderate chronic GVHD were observed in $21.88 \%$ and $12.50 \%$ of the cases. No statistically significance was observed between the MSD and MUD group on engraftment, GVHD and complications including infection and hemorrhagic cystitis. The median follow-up time was $38.60\left(1.37^{\sim} 140.83\right)$ months. To the date of October 31th 2021, 5 died and 27 (84.38\%) survived. The 5-year OS rate was not statistically significant between the MSD and MUD group $(84.8 \% \pm 10.0 \%$ vs $82.4 \% \pm 9.2 \%, \mathrm{P}=0.674)$. Conclusions: The application of UC-MSCs in the treatment of RSAA in PBSC transplantation is reliable and safe, which can significantly reduce the incidence of GVHD and severe transplantation-related complications and effectively improve patients' life quality. Therefore, the method can be used as an active treatment option for patients with RSAA.
\end{abstract}

\section{Hosted file}

manuscript.doc available at https://authorea.com/users/446892/articles/546015-cotransplantation-of-umbilical-cord-mesenchymal-stem-cells-and-peripheral-blood-stemcells-in-children-and-adolescents-with-refractory-severe-aplastic-anemia

\section{Hosted file}

Abbreviations.docx available at https://authorea.com/users/446892/articles/546015-co-
transplantation-of-umbilical-cord-mesenchymal-stem-cells-and-peripheral-blood-stem-
cells-in-children-and-adolescents-with-refractory-severe-aplastic-anemia Hosted file

Table1.docx available at https://authorea.com/users/446892/articles/546015-cotransplantation-of-umbilical-cord-mesenchymal-stem-cells-and-peripheral-blood-stemcells-in-children-and-adolescents-with-refractory-severe-aplastic-anemia 


\section{Hosted file}

Table 2.docx available at https://authorea.com/users/446892/articles/546015-cotransplantation-of-umbilical-cord-mesenchymal-stem-cells-and-peripheral-blood-stemcells-in-children-and-adolescents-with-refractory-severe-aplastic-anemia

\section{Hosted file}

Table 3.docx available at https://authorea.com/users/446892/articles/546015-cotransplantation-of-umbilical-cord-mesenchymal-stem-cells-and-peripheral-blood-stemcells-in-children-and-adolescents-with-refractory-severe-aplastic-anemia

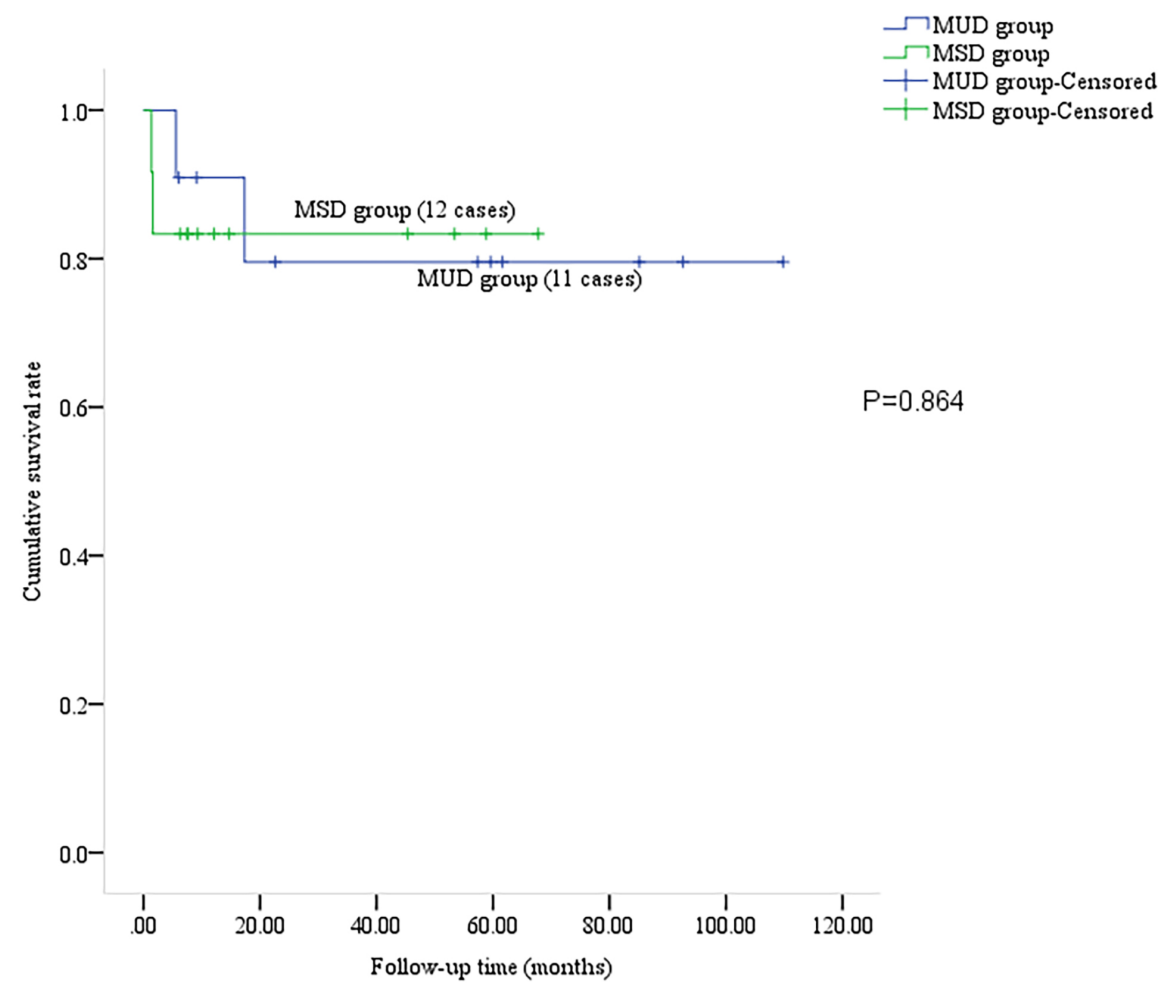

